\title{
Ikhtilaf Hukum Solat Fardu Berjemaah Menurut Mazhab Syafie: Satu Sorotan Kajian
}

\author{
Hasna Bidin, ${ }^{1 *}$ Ahmad Syukran Baharuddin ${ }^{1}$, Mohd Ismail Mustari ${ }^{2}$ \\ ${ }^{1}$ Postgraduate Student, Faculty of Islamic Civilisation, Universiti Teknologi Malaysia, 81310 UTM Johor Bahru, Johor \\ ${ }^{2}$ Associate Professor, Faculty of Islamic Civilisation, Universiti Teknologi Malaysia, 81310 UTM Johor Bahru, Johor \\ *Corresponding author: hasnabinbidin@yahoo.com
}

Article history

Received: 2015-02-10
Received in revised form: $2015-09-23$
Accepted: 2015-10-01

\begin{abstract}
This study discusses the ikhtilaf on the congregation in performing prayers by Shafi'i School. This issue arises because some of the Muslim in community are still confused about the law of congregation in prayers and underestimate the importance of it. It is a result of lack of knowledge towards the importance of congregation in prayer and its demands in Islam. This study focuses on the meaning of prayer, its wisdom and benefits, discussion of the differences among legal scholars of Shafi'i and the views of the strongest in the Shafi'i school. The methodology used in this study were based on the literature review and reference materials such as books and journals publishing on this subject. Analysis was made using deductive methodology which was specific to the conclusion of public information. The results obtained from this study showed that demand prayers in prayers is fardu kifayah for all Muslims in the opinion of the strongest in Shafi'i sect. Fardu kifayah is a communal obligation under the liability of Muslims who live in a community and shared responsibility.
\end{abstract}

Keywords: Congregational prayer, Shafi'i School, istidlal, istinbat, usul fiqh

\begin{abstract}
Abstrak
Kajian ini membincangkan tentang ikhtilaf berjemaah di dalam solat fardu menurut mazhab Syafie. Isu ini timbul kerana terdapat dalam kalangan masyarakat Islam yang masih keliru terhadap hukum berjemaah dalam solat fardu serta memandang remeh terhadap kepentingan solat berjemaah. Perkara ini berlaku disebabkan pengetahuan mereka yang masih kabur dan kurang jelas terhadap kepentingan solat berjemaah dan tuntutannya dalam Islam. Kajian ini bertujuan memberi tumpuan kepada pengertian solat berjemaah, hikmah serta kelebihannya, perbincangan tentang perbezaan hukumnya dalam kalangan ulama' Syafie dan rumusan perbincangan terhadap pandangan yang terkuat dalam mazhab Syafie. Metod yang digunakan dalam kajian ini ialah kajian kepustakaan dengan berpandukan kepada bahan rujukan seperti buku-buku dan jurnal-jurnal penerbitan berkaitan tajuk ini. Analisis adalah menggunakan metodologi deduktif iaitu membuat kesimpulan khusus daripada maklumat yang umum. Hasil yang diperolehi daripada kajian ini menunjukkan bahawa tuntutan solat berjemaah dalam solat fardu adalah merupakan kewajipan fardu kifayah ke atas umat Islam menurut pendapat terkuat dalam mazhab Syafie. Kewajipan fardu kifayah adalah merupakan kewajipan di bawah tanggungan umat Islam yang mendiami sesebuah komuniti atau desa. Sekiranya ada sebilangan kecil daripada mereka yang melakukannya, maka gugurlah kewajipan tersebut.
\end{abstract}

Kata kunci: Solat berjemaah, mazhab Syafie, istidlal, istinbat, usul fiqh 


\subsection{PENDAHULUAN}

Umum mengetahui bahawa solat fardu lima waktu adalah merupakan benteng yang paling ampuh bagi setiap muslim untuk menyekat dan menahan dirinya daripada melakukan maksiat dan dosa. Apatah lagi ianya akan lebih berkesan jika dilakukan solat fardu tersebut dengan berjemaah. Sesungguhnya solat berjemaah mengandungi banyak kelebihan dan fadhilat yang akan dikecapi oleh setiap individu muslim yang melaksanakannya. Tetapi malangnya apa yang berlaku pada hari ini kita dapati bahawa sifat berlumba-lumba didalam menunaikan ibadat sudah semakin terhakis dalam diri dan hati umat Islam. Mereka semua lebih cenderung dalam melaksanakan tuntutan hidup yang bersifat duniawi semata-mata demi memenuhi kehendak kehidupan seharian seperti berkerjaya, berkeluarga dan bermasyarakat sahaja. Mereka tidak peka terhadap tuntutan rohani dan tanggungjawab kepada Allah SWT dengan melaksanakan ibadah yang wajib seperti solat fardu di samping menambahkan amalan-amalan sunat untuk mendekatkan diri kepada Allah SWT.

Untuk keluar daripada kelalaian dan penyakit tersebut, formula yang paling berkesan ialah umat Islam perlu kembali berlumba-lumba menunaikan solat berjemaah disamping mengajak dan menyeru orang lain untuk turut serta solat berjemaah (Mohd Subki, 2011:17). Hal yang demikian ini akan mengembalikan kegemilangan umat Islam sepertimana zaman Rasulullah SAW dan para sahabatnya yang menjadikan solat berjemaah sebagai rutin harian mereka bagi menzahirkan kekuatan umat Islam serta membangkitkan kelazatan beribadah kepada Allah SWT.

\subsection{SOLAT FARDU BERJEMAAH DAN TUNTUTANNYA}

Secara etimologi, 'jamaah' diertikan sebagai satu perhimpunan yang tidak terhad kepada manusia, boleh jadi kepada tumbuhan dan juga haiwan (Ibn Manzur,1994). Menurut Epistemologi syara', solat berjemaah pula ialah mewujudkan satu ikatan solat dan pertalian di antara imam dan makmum (al-Zuhayli, t.t.).Terdapat pandangan lain yang mendefinisikan solat berjemaah sebagai solat beramai-ramai yang terdiri daripada sekurang-kurangnya dua orang iaitu seorang imam dan seorang makmum. Semakin ramai bilangan makmum, maka akan semakin besar pula fadhilat pahalanya (al-Syarbini, 1994). Menurut Ibn Qudamah (1968) pula bahawa solat jemaah dapat dilakukan oleh dua orang atau lebih tanpa khilaf di kalangan para ulama'.

Solat fardu iaitu disebut sebagai al-Solah al-Mafrudah atau al-Solah al-Maktubah adalah solat fardu lima waktu yang telah diwajibkan ke atas seseorang muslim yang mukallaf (Ibn Qudamah, 1968; al-Syarbini, 1994). Seseorang muslim adalah dituntut untuk mengerjakan solat sebanyak lima kali sehari semalam mengikut waktuwaktu yang telah ditetapkan oleh Allah SWT. Solat yang diwajibkan itu dikenali dengan beberapa nama seperti $a l$ Solawat al-Khams iaitu solat fardu yang lima. Di dalamnya terkandung lima jenis solat iaitu zohor, asar, maghrib, isya' dan subuh (Ali Mursi, 2001: 258).

Skop solat berjemaah yang akan dibincangkan pada tajuk ini akan memberi tumpuan kepada solat fardu. Hal ini kerana setiap muslim akan menunaikan solat fardu lima waktu dalam kehidupan seharian. Dari itu, perlu diperjelaskan tentang tuntutan solat berjemaah dalam solat fardu menurut mazhab Syafie kerana terdapat ramai dikalangan umat Islam yang masih kabur tentang tuntutan solat berjemaah dalam solat fardu dan hukumnya atau mungkin mereka mengetahuinya tetapi sengaja tidak memperdulikannya kerana keasyikan mereka dengan kehidupan duniawi semata-mata (Mohd Subki, 2011). Solat berjemaah disyariatkan dalam Islam selepas nabi SAW berhijrah ke Kota Madinah. Ia tidak disyariatkan di Makkah kerana pengaruh kafir Quraisy masih menguasai Makkah.

Oleh sebab itu, apabila direnung kembali lembaran sirah nabawi didapati bahawa perkara utama yang dilakukan oleh Rasulullah SAW ketika sampai di Quba' dan Madinah ialah membina masjid (al-Mubarkafuri, t.t.). Hal sedemikian dilakukan bertujuan menghidupkan syiar solat berjemaah dalam kalangan umat Islam dalam menunaikan solat fardu lima waktu (al-Syatibi,1997). Mengenai dalil-dalil umum tentang tuntutan solat berjemaah ke atas orang Islam terdapat keterangannya di dalam al-Quran dan al-Sunnah sepertimana berikut: 


\section{Dalil al-Quran}

Firman Allah SWT menjelaskan tentang keutamaan solat berjemaah sekalipun dalam keadaan perang sekaligus menunjukkan pahala yang besar bagi mereka yang solat berjemaah. Allah SWT berfirman:

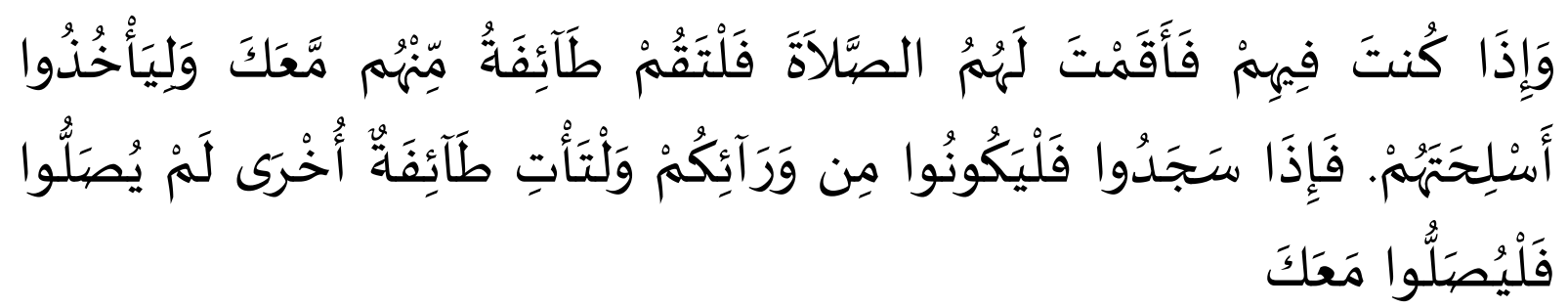

Terjemahan: "Dan apabila engkau (wahai Muhammad) berada dalam kalangan mereka (semasa perang), lalu engkau mendirikan sembahyang dengan (menjadi imam) mereka, maka hendaklah sekumpulan dari mereka berdiri (mengerjakan sembahyang) bersama-samamu, dan hendaklah mereka menyandang senjata masing-masing; kemudian apabila mereka telah sujud, maka hendaklah mereka berundur ke belakang (menjaga serbuan musuh) dan hendaklah datang pula sekumpulan puak yang lain (yang kedua) yang belum sembahyang (bagi menjaga serbuan musuh),maka hendaklah mereka bersembahyang (berjemaah) bersama-samamu. (al-Nisa', 4: 102)

Kesimpulan dari ayat di atas memerintahkan solat berjemaah pada ketika ketakutan di dalam peperangan, maka sudah tentu dalam masa aman lebih dituntut lagi untuk melakukannya (Khatib Syarbini,1994: 229). Hal ini juga dibuktikan dengan tauladan yang ditunjukkan oleh Rasulullah S.A.W yang istiqamah menunaikan solat fardu dengan berjemaah dalam banyak lokasi peperangan (al-'Arabi,1995:491).

2. Dalil al-Sunnah

Manakala hadis Rasulullah SAW yang menjelaskan tentang kelebihan solat berjamaah, antaranya sabda Rasulullah SAW daripada Abdullah Ibn Umar ra, iaitu: (Bukhari, 2001:645; Muslim, 1999:650):

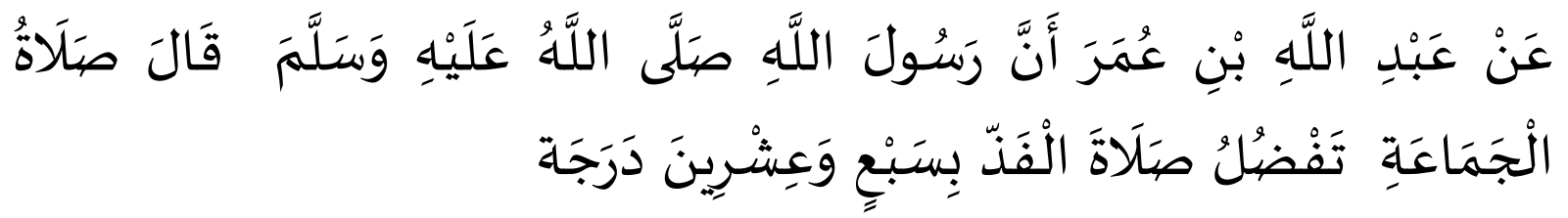

Maksudnya: "Daripada Abdullah bin Umar ra, katanya; sesungguhnya Rasulullah S.A.W bersabda: Sembahyang berjamaah lebih afdal daripada sembahyang seorang diri dengan dua puluh tujuh darjat." (Riwayat Bukhari dan Muslim)

Kesimpulan dari keterangan di atas dapatlah difahami bahawa solat berjamaah mempunyai kelebihan dan keutamaan berbanding solat bersendirian. Hal ini kerana setiap orang yang berada dalam jamaah akan mendatangkan satu kebaikan seterusnya digandakan setiap satu kebaikan kepada sepuluh kebaikan. Hal ini menunjukkan rahmat Allah SWT dan kasih-sayangnya kepada hamba-hambanya yang berjemaah dalam melakukan ibadah terutamanya solat fardu (Ibn Hajar al-Asqalani, 1997: 160-161).

\subsection{HIKMAH DAN KELEBIHAN SOLAT BERJEMAAH}

Solat berjamaah mengandungi banyak hikmah merangkumi yang tersurat dan tersirat. Antara hikmah-hikmah solat berjamaah ialah dapat menyuburkan sifat mahabbah (kasih-sayang), taa'ruf (berkenal-kenalan) dan semangat kerjasama dalam kalangan anggota masyarakat Islam. Dengan pertemuan secara langsung melalui solat berjemaah dapat memecahkan perasaan iri hati dan benci dalam diri setiap muslim serta membangkitkan semangat kerjasama dalam menegakkan kebenaran dan menghancurkan kebatilan (Mustafa et. al., 2004:411-412). Selain itu, solat berjemaah dapat melatih setiap individu muslim supaya sentiasa mematuhi peraturan hidup serta cintakan ketaatan 
dalam perkara kebajikan dan ma'ruf sehingga memperolehi kesejahteraan hidup di dunia dan akhirat (Mohd Salleh, 2003:5-6). Melalui solat berjemaah juga dapat menyediakan satu ruang bagi orang-orang yang jahil untuk menimba ilmu-ilmu agama daripada orang alim serta berkongsi pandangan dan maklumat dalam menangani permasalahan kehidupan (Bujairimi, 1950:287). Selain itu, solat berjemaah juga dapat menzahirkan syiar Islam dalam kehidupan seharian umat Islam kerana apabila seruan azan berkumandang, ia sebagai tanda bahawa sesuatu tempat itu ada orang Islam dan ada tempat solat (Mohd Subki, 2011:134). Manakala kelebihan dan keistimewaan solat berjemaah terserlah pada hadis Rasulullah SAW yang menjelaskan tentang fadhilat dan kelebihan solat berjemaah dengan ganjarannya 27 kali ganda lebih besar dari solat bersendirian. Selain itu, terdapat banyak lagi hadis-hadis yang lain menyebut tentang fadhilat solat berjemaah, di antaranya ialah:

1. Mendapat dua jaminan kelepasan iaitu kelepasan dari api neraka dan dari sifat munafiq

Hadis Rasulullah S.A.W daripada Anas bin Malik ra, iaitu: (Tirmidzi, t.t.: 241):

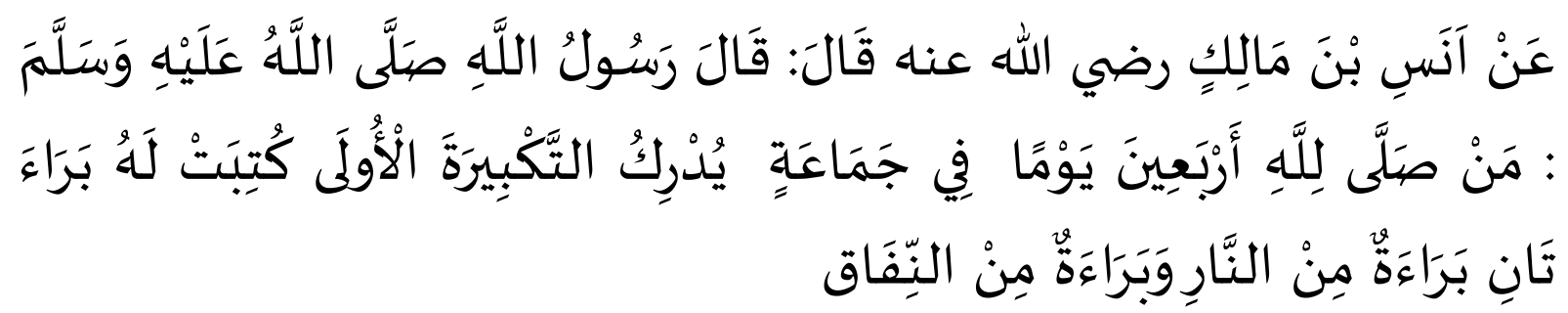

Maksudnya: Daripada Anas ra, katanya; bahawa Rasulullah S.A.W telah bersabda: "Sesiapa yang bersolat jamaah kerana Allah selama empat puluh hari dengan berjamaah, mendapat takbir yang pertama ditulis baginya dua kelepasan: kelepasan daripada api neraka dan kelepasan daripada nifaq. (Riwayat alTirmidzi)

Kesimpulan yang dapat difahami daripada huraian di atas ialah betapa hebatnya janji Allah SWT kepada orangorang yang memelihara solat berjemaah seawal takbir yang pertama bersama imam akan mendapat dua jaminan keselamatan. Jaminan yang pertama ialah mereka ini akan dilepaskan dan dibebaskan daripada azab neraka, manakala jaminan kedua pula ialah mereka akan dibebaskan daripada sifat orang-orang munafiq. Adapun yang dimaksudkan dengan takbir pertama ialah takbiratulihram yang dilakukan oleh makmum mengiringi takbiratulihram yang dilakukan oleh imam (al-Mubarkafuri, 2001:506).

2. Solat berjemaah dapat menghapuskan dosa-dosa yang lalu

Sabda Rasulullah S.A.W dalam hadis yang lain daripada Abu Hurairah ra, iaitu: (Ibn Hibban, 1996:1730; Muslim, 1999:233):

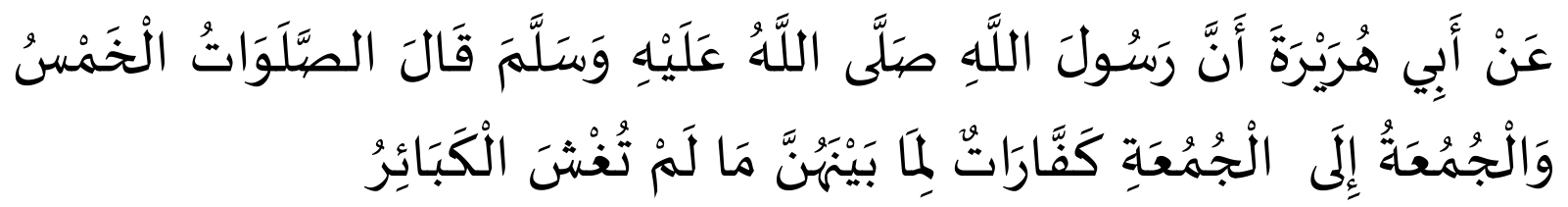

Maksudnya: "Dari Abi Hurairah ra, berkata; sesungguhnya Rasulullah S.A.W bersabda: Sembahyang fardu hingga fardu berikutnya dan sembahyang jumaat hingga jumaat berikutnya menjadi penebus dosa-dosa yang terjadi di antara itu selama ditinggalkan dosa-dosa besar." (Riwayat Muslim dan Ibn Hibban)

Menurut al-Nawawi (1994:234), hadis di atas menjelaskan bahawa solat fardu yang sempurna dan solat jumaat akan menghapuskan semua dosa-dosa kecuali dosa besar. Hal ini menunjukkan bahawa pengampunan dosa akan diberikan oleh Allah SWT kepada setiap muslim yang bersolat fardu lima waktu dengan berjemaah dan solat jumaat selagi mereka tidak mengerjakan dosa-dosa besar. Adapun dosa-dosa besar tidak dapat diampuni melalui ibadat solat disebabkan ianya hanya dapat diampuni dengan bertaubat kepada Allah SWT. 
Kesimpulannya, dapat difahami bahawa ibadah solat dapat menghapuskan segala dosa-dosa kecil yang telah dilakukan oleh seseorang muslim dengan syarat tidak melakukan dosa-dosa besar. Jika demikian keadaannya, solat fardu berjemaah juga akan menjamin pengampunan dosa-dosa kecil jika dihindarkan dosa-dosa yang besar.

\subsection{PERBINCANGAN IKHTILAF HUKUM SOLAT BERJEMAAH}

Selepas mengetahui hikmah dan kelebihan solat berjemaah, berikut dibincangkan pendapat ulama' mazhab Syafie berkaitan hukum solat berjamaah bertujuan supaya sunnah berjamaah itu dapat dihayati dan dimakmurkan dalam kehidupan masyarakat Islam di Malaysia. Terdapat tiga perbezaan hukum solat berjemaah dalam mazhab Syafie iaitu fardu ain, fardu kifayah, dan sunat muakkad (Abdul Aziz,1999:565).

\section{Wajib Fardu 'Ain}

Terdapat pendapat dalam mazhab Syafie yang mengatakan bahawa solat berjamaah hukumnya fardu Ain tetapi bukanlah syarat sah solat. Dalam erti kata yang lain, solat berseorangan hukumnya harus dan sah tetapi dia tetap berdosa kerana tidak solat secara berjamaah. Pengertian fardu ain ialah segala sesuatu yang wajib dilaksanakan oleh setiap individu serta perlaksanaan yang telah dilakukan oleh sebilangan golongan atau kaum tidak akan menggugurkan kewajipannya ke atas sebahagian yang lain seperti iman dan seumpamanya (Ali Jurjani, 1983:165). Pendapat ini dipegang oleh Ibn Munzir dan sebilangan kecil pengikut mazhab Syafie. Dasar pendapat ini adalah daripada dalil berikut:

1. Dalil al-Quran:

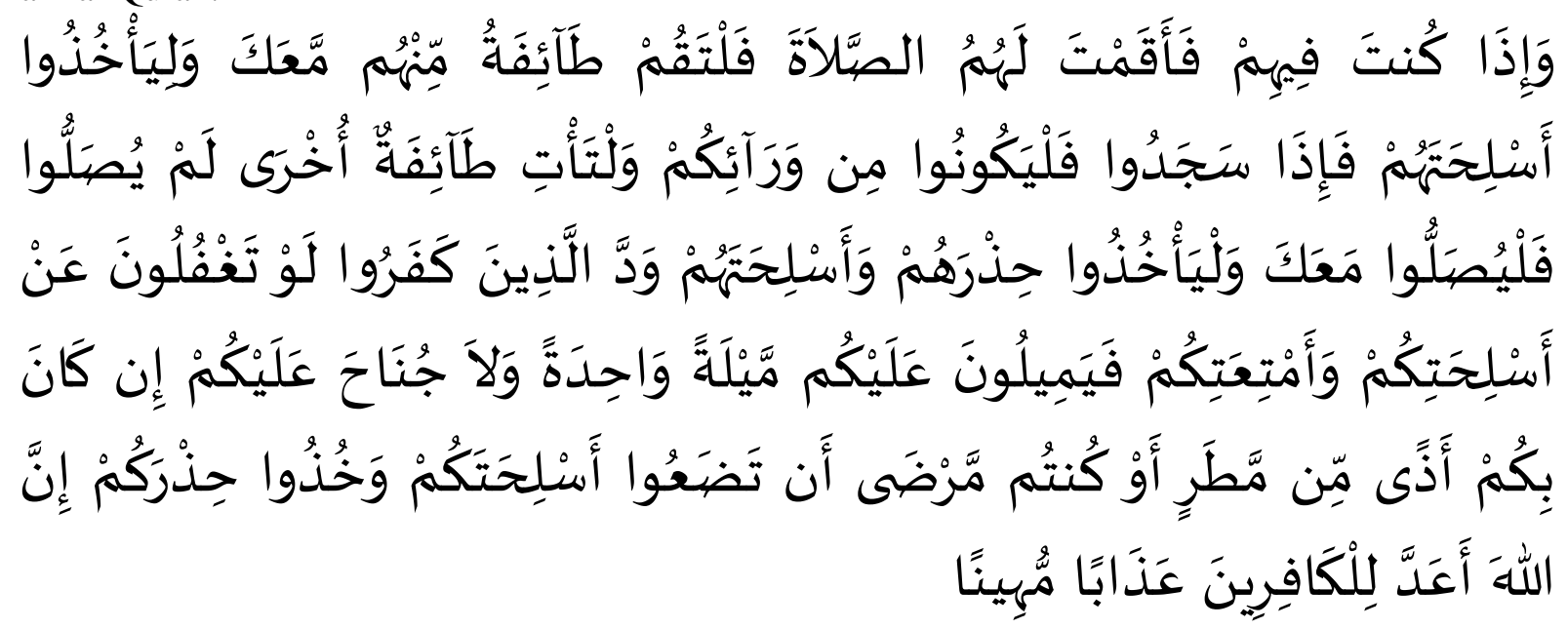

Terjemahan: Dan apabila kamu berada di tengah-tengah mereka (sahabatmu), lalu kamu hendak mendirikan solat bersama-sama mereka, maka hendaklah segolongan dari mereka berdiri (solat) besertamu dan menyandang senjata, kemudian apabila mereka (yang solat besertamu) sujud (telah menyempurnakan seraka'at), maka hendaklah mereka pindah dari belakangmu (untuk menghadapi musuh) dan hendaklah datang golongan yang kedua yang belum bersolat, lalu bersolatlah mereka denganmu, dan hendaklah mereka bersiap-siaga dan menyandang senjata. Orang-orang kafir ingin supaya kamu lengah terhadap senjatamu dan harta bendaтu, lalu mereka menyerbu kamu dengan sekaligus. Dan tidak ada dosa atasmu meletakkan senjata-senjatamu, jika kaтu mendapat sesuatu kesusahan karena hujan atau kerana kamu memang sakit; dan siap-sedialahlah kamu. Sesungguhnya Allah telah menyediakan azab yang menghinakan bagi orangorang kafir itu. (al-Nisa', 4:102)

Ayat di atas menekankan betapa pentingnya solat berjemaah dalam keadaan peperangan dan cara perlaksanaannya. Ulama' yang mengambil ayat ini sebagai dalil kefarduan solat berjemaah dengan cara al-awla iaitu mengi'tibarkan bahawa dalam keadaan peperangan juga diwajibkan solat berjemaah, maka dalam keadaan aman lebih-lebih lagi (al-Najdi, 1977; Ibn Taymiyyah, 1995, Khatib Syarbini, 1994: 229).

Perbincangan: Ayat ini hanya berada dalam konteks pengajaran kaedah untuk solat dalam keadaan peperangan dan tidak aman, bukanlah menjadi dalil kepada wajib fardu ain kepada solat berjemaah. 


\section{وَأَقِيمُوا الصَّلالَةَ وَءَاتُوا الزَّكَاةَ وَارْكَعُوا مَعَ الرَّاكِعِينَ}

Terjemahan: Dan dirikanlah solat, tunaikanlah zakat, dan rukuklah bersama orang-orang yang rukuk. (alBaqarah, 2:43)

Ayat tersebut menggunakan fi'il amr iaitu kata kerja suruhan. Suruhan mengerjakan solat dan menunaikan zakat serta literalnya suruhan untuk rukuk bersama mereka yang ruku'. Penggunaan kata kerja suruhan dalam kaedah usul fiqh adalah menunjukkan kepada kewajipan kepada sesuatu perkara tersebut sehingga tiada dalil-dalil lain yang menyanggahnya. Lafaz 'al-raki'in' pula menunjukkan mutlaq. Suruhan dalam keadaan mutlaq menandakan ianya sesuatu yang wajib. Orang-orang yang rukuk ditafsirkan sebagai mereka yang solat berjemaah (al-Zamakhshari, 1987). Maka suruhan dalam ayat ini merujuk kepada kewajipan untuk menunaikan solat dan berjemaah dalam melakukannya.

Perbincangan: Ayat ini menyatakan perbezaan antara ibadat sorang muslim dan juga yahudi yang mana ibadat yahudi tidak mempunyai ruku' (al-Baghawiy, 2000). Ayat ini juga adalah isyarat kepada melakukan solat dengan menunaikan segala rukun dan syaratnya. Maka konteks ayat ini bukanlah ditujukan untuk menjadi dalil kepada wajib fardu 'ain bagi solat berjemaah (al-Baghawiy, 2000).

2. Dalil hadis:

Hadis Rasulullah S.A.W yang diriwayatkan oleh Abu Daud, Muslim dan Ibn Majah daripada Abu Hurairah ra, (Abu Daud, 1995: 548; Muslim,1999 : 651; Ibn Majah, 1998 : 791):

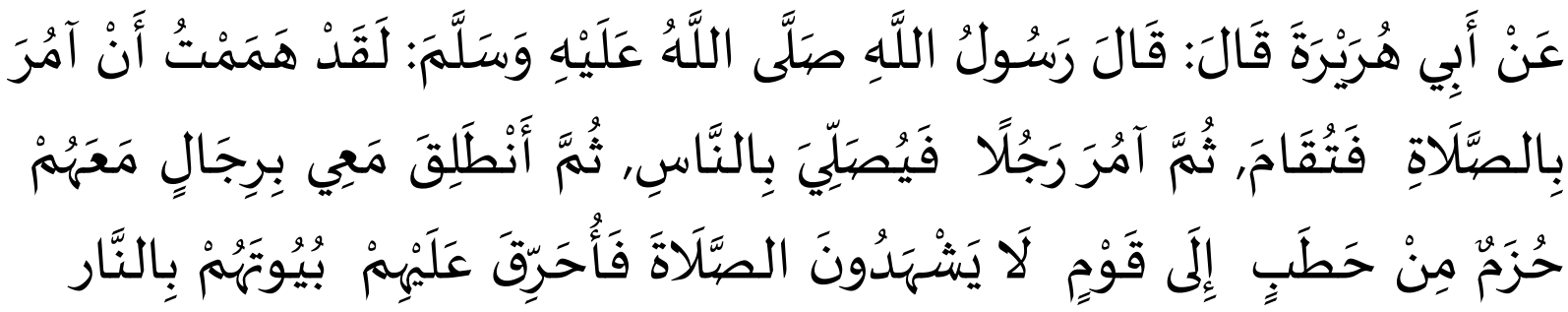

Maksudnya: Dari Abi Hurairah RA berkata; bahawa Rasulullah S.A.W bersabda: " Sesungguhnya memang aku bercadang untuk menyuruh agar diiqamahkan sembahyang dan aku suruh seseorang untuk mengimami para jemaah, dan aku pula keluar dengan beberapa orang lelaki yang membawa bersama mereka beberapa ikatan kayu api untuk pergi ke rumah-rumah orang yang tidak hadir kepada solat berjemaah, lalu aku bakarkan rumah-rumah mereka." (Riwayat Muslim, Abu Daud dan Ibn Majah)

Zahir hadis ini menunjukkan kewajipan fardu ain terhadap lelaki. Hadis tersebut juga menjadi dalil bagi golongan yang mewajibkan solat berjemaah kerana sekiranya solat berjemaah tersebut hukumnya sunat nescaya Rasulullah S.A.W tidak memberi amaran kepada orang yang meninggalkannya dengan ancaman untuk dibakar rumah-rumah mereka (al-Syaukani,2003:404; al-Kahlani, t.t.). Jika solat berjemaah hukumnya fardu kifayah pula, pastilah Rasulullah S.A.W dan orang-orang yang berjemaah bersamanya akan melakukan perkara sedemikian (membakar rumah-rumah orang yang meninggalkan solat berjemaah). Dengan demikian, tiada ancaman melainkan melakukan perkara haram dan meninggalkan yang wajib. Hal ini menunjukkan bahawa suruhan dan tuntutan solat berjemaah adalah kewajipan fardu ain ke atas setiap individu muslim.

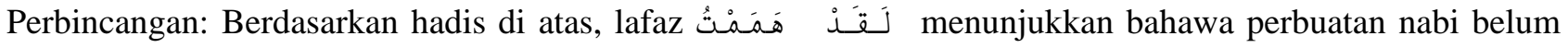
berlaku. Sekiranya sesuatu perkara itu diwajibkan, sudah tentu hukuman tersebut dilaksanakan. Hadis ini juga merujuk kepada kaum munafiqin yang berat untuk mengerjakan solat isyak dan subuh kerana kegelapan malam dan kelazatan tidur sewaktu fajar bukanlah kepada kaum muslimin seperti dalam hadis lain yang menjelaskan mengenai ciri-ciri munafik dalam mengerjakan solat seperti hadis ليس صلاة أثقل على المنافقين من العشاء والثجر dan beberapa lagi hadis lain yang menyebut mengenai ciri-ciri munafik (Mohd Haidzir, 2014:9; al-`Asqalani, 1997:184-185). 
Dalil seterusnya adalah hadis yang diriwayatkan oleh Abu Daud, Ibn Hibban dan Nasaei daripada Abu Darda' ra, (Abu Daud,1995 : 547; Ibn Hibban, 1996 : 2098; Nasa'i, 2003 : 847):

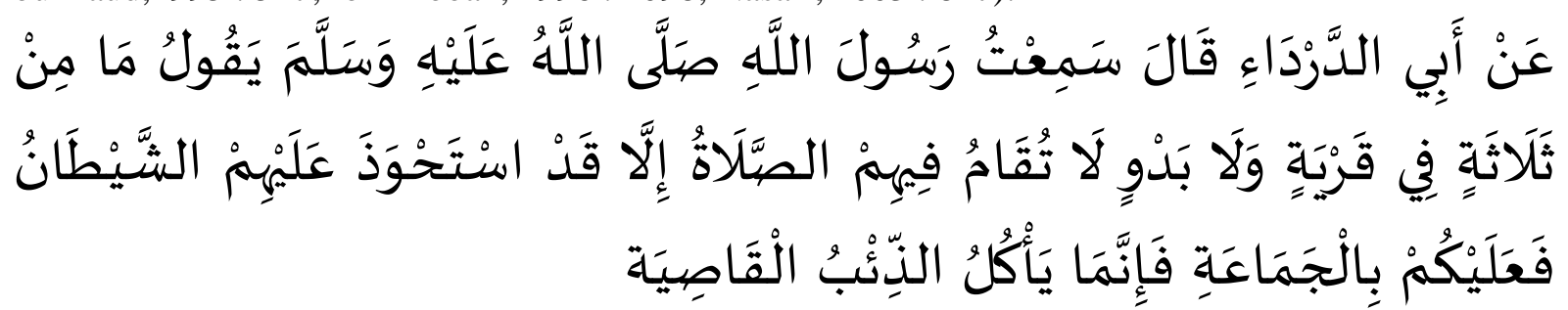

Maksudnya: Tidaklah ada tiga orang dalam satu perkampungan atau pedalaman tidak ditegakkan pada mereka solat, kecuali Syaitan akan menguasainya. Berjemaahlah kalian, karena serigala hanya memangsa kambing yang sendirian. (Riwayat Abu Daud, Ibn Hibban dan Nasaei)

Berdasarkan hadis ini, kaedah usul fiqh yang digunakan dalam istinbat hukum adalah dengan melihat kepada لا يصلون yang menggunakan sighah merujuk kepada suruhan yang berbentuk fardu ain dan bukan الصلاة yang merujuk kepada suruhan fardu kifayah (al-Syaukani, 2003:484). Hadis ini juga menunjukkan meninggalkan solat berjemaah itu adalah sebahagian daripada penguasaan syaitan terhadap seseorang dan ianya wajib dihindari, maka ianya termasuk dalam fardu 'ain. Saib bin Hubais mengatakan bahawa Jemaah yang dimaksudkan adalah Jemaah dalam solat. Menurut al-Syaukani (2003: 484), hadis di atas menjelaskan tentang kewajipan solat berjamaah kerana meninggalkannya akan menyebabkan kepada sesebuah masyarakat atau desa mudah dikuasai syaitan serta akan berleluasalah kejahatan dan kemaksiatan. Maka sebarang kemudharatan hendaklah dikekang secara baik. Kesimpulannya, solat berjemaah akan membawa kesejahteraan dan keamanan sesebuah desa atau masyarakat kerana solat berjemaah itu adalah sumber kekuatan ummah dan lambang kepada penyatuan umat Islam.

Perbincangan: Hadis ini juga menjadi perbincangan dalam bab perpaduan dan berada dalam jemaah. Ulama berselisih pendapat, sama ada hadis ini merujuk kepada jemaah dalam solat atau pun jemaah dalam pimpinan.

\section{Wajib Fardu Kifayah}

Menurut al-Nawawi dan beberapa tokoh ulama' lain dalam mazhab Syafie menegaskan bahawa solat berjamaah hukumnya adalah fardu kifayah. Pengertian fardu kifayah disini bermaksud setiap kewajipan yang mesti dilaksanakan oleh mukallaf tertentu dan dengan perlaksanaan mereka itu, maka terlepaslah kefarduan tersebut itu kepada yang lain seperti jihad dan solat jenazah (al-Jurjani, 1983:165). Adapun solat fardu secara berjamaah ini wajib dilaksanakan di tempat-tempat yang boleh menampakkan syiar jamaah dan Islam seperti di masjid, musolla atau madrasah. Tetapi jika semua bersepakat melaksanakan solat jamaah di rumah masing-masing yang sama sekali tidak menampakkan syiar Islam, maka tidak gugur kewajipan solat berjemaah tersebut yang merupakan fardu kifayah ke atas mereka. Pendapat inilah yang masyhur dan muktamad serta menjadi pegangan sebahagian besar para ulama' dalam mazhab Syafie berdasarkan dalil berikut:

1. Dalil al-Quran:

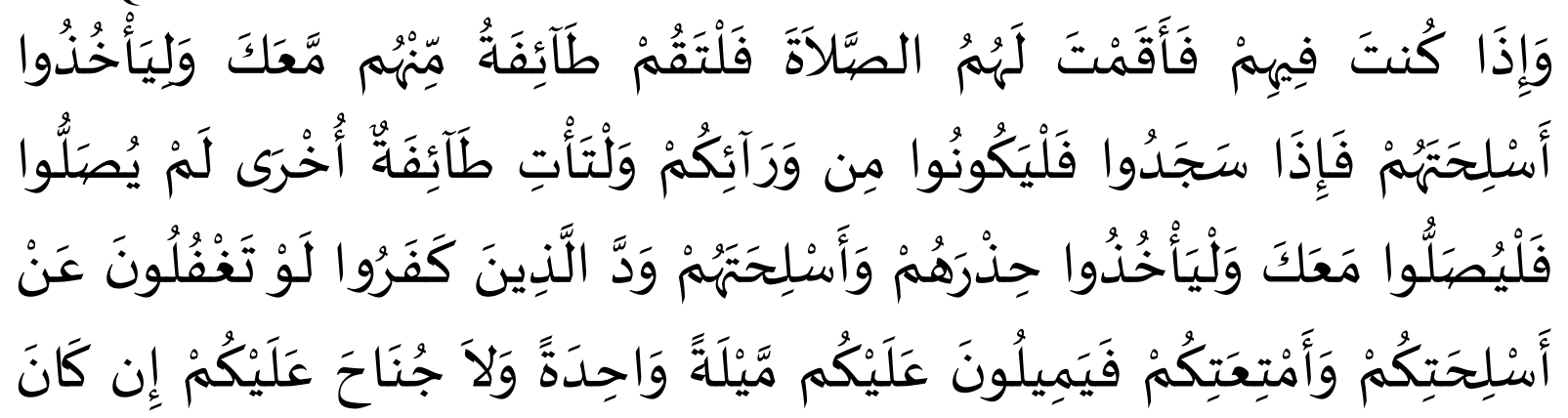




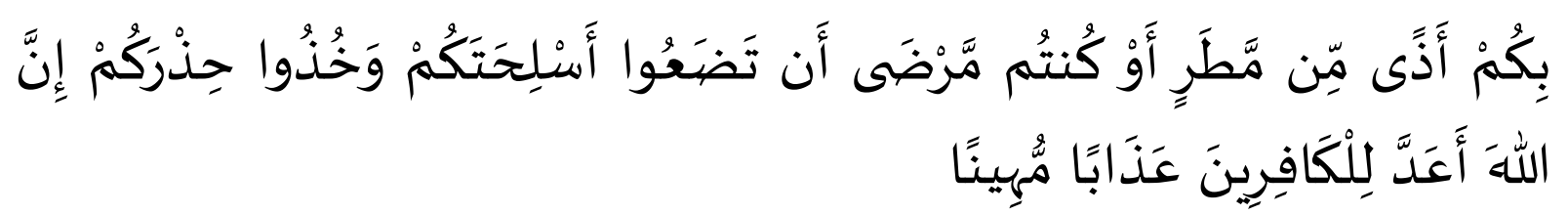

Dan apabila kamu berada di tengah-tengah mereka (sahabatmu), lalu kamu hendak mendirikan solat bersama-sama mereka, maka hendaklah segolongan dari mereka berdiri (solat) besertamu dan menyandang senjata, kemudian apabila mereka (yang solat besertamu) sujud (telah menyempurnakan serakaat), maka hendaklah mereka pindah dari belakangmu (untuk menghadapi musuh) dan hendaklah datang golongan yang kedua yang belum bersolat, lalu bersolatlah mereka denganmu, dan hendaklah mereka bersiap-siaga dan menyandang senjata. Orang-orang kafir ingin supaya kamu lengah terhadap senjatamu dan harta bendamu, lalu mereka menyerbu kamu dengan sekaligus. Dan tidak ada dosa atasmu meletakkan senjatasenjatamu, jika kamu mendapat sesuatu kesusahan karena hujan atau karena kamu memang sakit; dan siapsiagalah kamu. Sesungguhnya Allah telah menyediakan azab yang menghinakan bagi orang-orang kafir itu. (al-Nisa', 4:102)

Ayat di atas bertujuan untuk memberi kaedah bagaimana solat dalam keadaan peperangan dan dalam keadaan tidak aman dan ianya bukanlah menjadi dalil kepada kewajiban fardu ain bagi solat Jemaah.

Perbincangan: Sekiranya ayat di atas bertujuan untuk kaedah solat dalam keadaan peperangan, maka akan ada rukhsah untuk meninggalkan jemaah bagi berjaga-jaga dari serangan musuh seperti mana dalam situasi keuzuran yang disebutkan di akhir ayat (Ali al-Sayyis et. al.,1996: 516, Rafie,1993: 361).

2. Dalil Hadis:

Hadis Rasulullah S.A.W yang diriwayatkan oleh Abu Daud, Ibn Hibban dan Nasaei daripada Abu Darda' ra, (Abu Daud,1995 : 547; Ibn Hibban, 1996 : 2098; Nasaei, 2003 : 847):

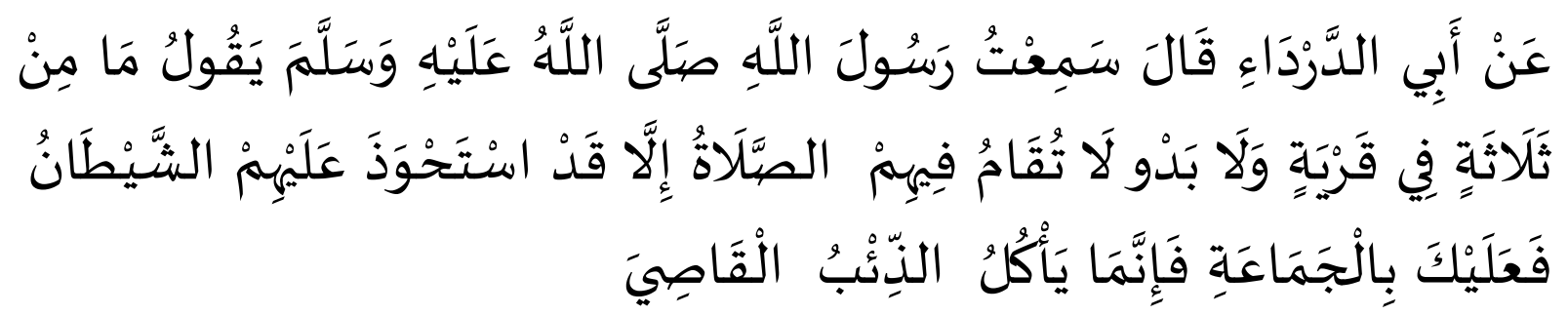

Maksudnya: Daripada Abi Darda' r.a., katanya; aku telah mendengar Rasulullah S.A.W bersabda: Tidak ada tiga orang (lelaki) dalam sesebuah kampung atau desa yang tidak mengerjakan sembahyang berjamaah, melainkan mereka (mudah) dikuasai syaitan (dengan menjadikan mereka mencuaikan perintah syara'); oleh itu hendaklah engkau sentiasa menyatukan diri dengan jama'ah (kerana dengan itulah sahaja engkau selamat dari angkara syaitan). (Riwayat Abu Daud, Ibn Hibban dan Nasa'i)

Berdasarkan hadis ini, kaedah usul fiqh yang digunakan dalam istinbat hukum adalah dengan melihat kepada

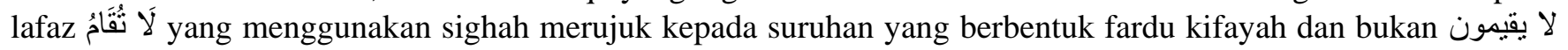
yang merujuk kepada suruhan fardu 'ain (al-Nawawi, t.t.:284; al-Syarbini, 1994:466; Mohd Haidzir, 2014:9).

Perbincangan: Sekiranya ayat di atas menunjukkan suruhan fardu kifayah bukannya fardu ain, sudah tentu penduduk sesebuah kampung tidak diancam dengan penguasaan syaitan akibat meninggalkan solat berjemaah berdasarkan hadis Rasulullah SAW yang diriwayatkan dari Abi Darda' r.a. Penguasaan syaitan terhadap diri seseorang muslim itu wajib dihindari, maka ianya termasuk dalam fardu 'ain (al-Syaukani, 2003:484).

Selain itu, hadis Rasulullah S.A.W yang diriwayatkan oleh Abu Daud, Muslim dan Ibn Majah daripada Abu Hurairah ra, (Abu Daud, 1995: 548; Muslim,1999 : 651; Ibn Majah, 1998 : 791): 


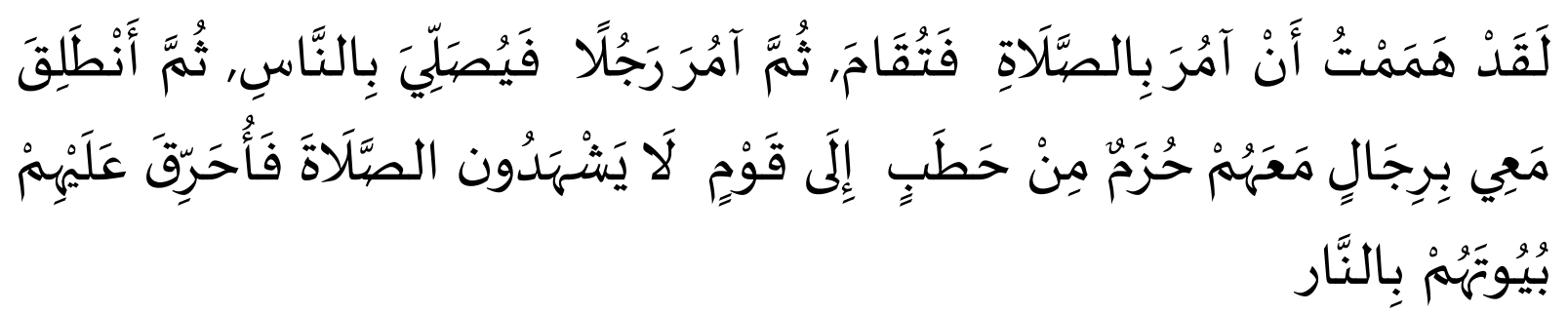

Maksudnya: Sesungguhnya memang aku bercadang untuk menyuruh agar diiqamahkan sembahyang dan aku suruh seseorang untuk mengimami para jemaah, dan aku pula keluar dengan beberapa orang lelaki yang membawa bersama mereka beberapa ikatan kayu api untuk pergi ke rumah-rumah orang yang tidak hadir kepada solat berjemaah, lalu aku bakarkan rumah-rumah mereka. (Riwayat Muslim, Abu Daud dan Ibn Majah)

Lafaz لَقَدْ هَمَمْتْ menunjukkan bahawa perbuatan nabi belum berlaku. Sekiranya sesuatu perkara itu diwajibkan, maka nabi tidak meninggalkan perkara tersebut (hukuman) untuk dilakukan. Juga hadis ini merujuk kepada kaum munafiqin yang berat untuk mengerjakan solat isya' dan subuh kerana kegelapan malam dan kelazatan tidur sewaktu fajar bukanlah kepada kaum muslimin (Mohd Haidzir, 2014:9).

Perbincangan: Sebab utama nabi tidak melakukan terus hukuman dengan membakar rumah-rumah mereka adalah kerana yang lebih layak untuk menghukum menggunakan api adalah Allah taala seperti hadis لا تعذبوا بعذاب الله Maka hadis ini tidak menjadi dalil bagi wajib fardu kifayah kepada solat berjemaah.

\section{Sunnah Muakkadah}

Hal ini adalah pendapat al-Rafie (t.t.) dan Imam Mawardi dalam kitab mereka (al-Nawawi, t.t.). Pengertian sunat muakkad di sini adalah bermaksud sunat yang sentiasa dilakukan oleh Rasulullah SAW secara berterusan. Sunat muakkad juga boleh bermaksud perkara-perkara yang digalakkan serta makruh jika ditinggalkan (al-Subki, 1994). Pendapat ini juga dikongsi sebagai pendapat bagi mazhab Hanafi dan Maliki dari tanah Sham dan Iraq. Dalil-dalil yang digunakan adalah:

1. Dalil hadis:

Hadis Rasulullah S.A.W yang diriwayatkan oleh Bukhari dan Muslim daripada Ibn Umar ra, (Bukhari, 2001: 645 ; Muslim,1999 : 650) :

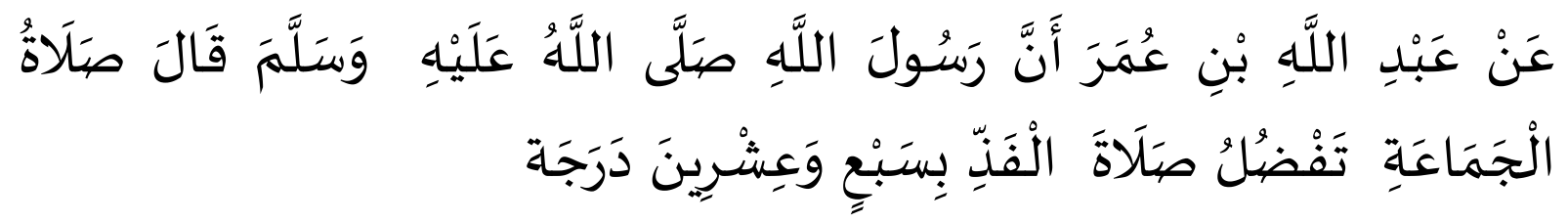

Maksudnya: Daripada Abdullah bin Umar ra, katanya; sesungguhnya baginda Rasulullah SAW bersabda:

Bahawa sembahyang berjamaah itu lebih afdhal daripada sembahyang seorang diri dengan dua puluh tujuh darjat. (Riwayat Bukhari dan Muslim)

Hadis ini menunjukkan bahawa terdapat ganjaran melebihi solat berseorangan bagi solat berjemaah iaitu dikenali sebagai afdhal. Konsep mufadhalah ini tidak akan berlaku sekiranya salah satu perkara yang dibandingkan itu adalah tidak sahih atau berdosa. Oleh itu, solat berjemaah hukumnya adalah sunat muakkad (al-Kahlani, t.t.).

Perbincangan: Sekiranya solat berjemaah itu hukumnya sunat, nescaya Rasulullah SAW tidak memberi amaran kepada orang yang meninggalkannya dengan ancaman untuk dibakar rumah- rumah mereka sebagaimana yang telah dinyatakan dalam hadis yang diriwayatkan oleh Abu Hurairah ra (al-Syaukani, 2003:404; al-Kahlani, t.t.).

Hadis dari Sahih Muslim dan hadis lain yang menunjukkan perihal solat sendirian antaranya: 


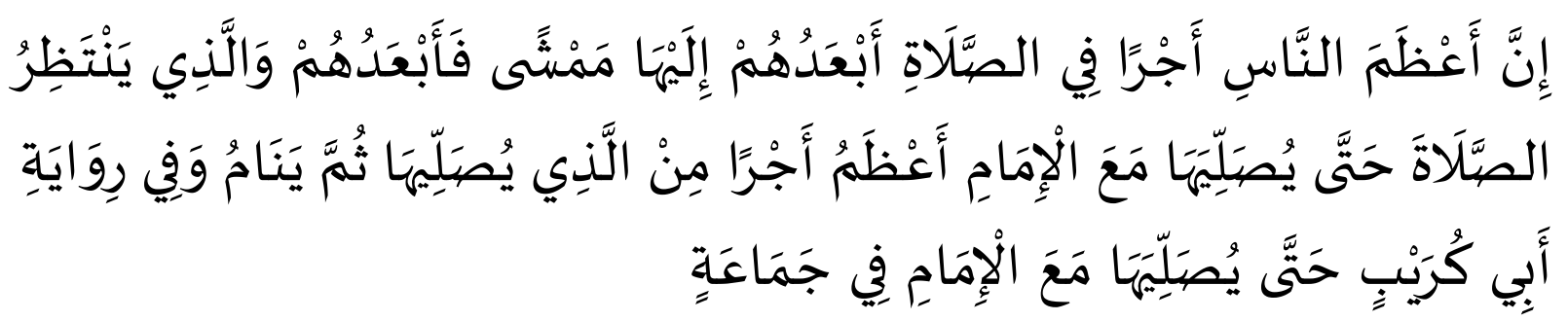

Maksudnya: Sesungguhnya, orang yang mendapat pahala paling besar dalam solat ialah yang paling jauh jalannya, kemudian yang lebih jauh. Orang yang menunggu solat sampai solat bersama imam, lebih besar pahalanya dari orang yang solat, kemudian tidur. Dalam riwayat Abu Kuraib, (disebutkan): sampai solat bersama imam dalam jamaah. (Muslim: 1064)

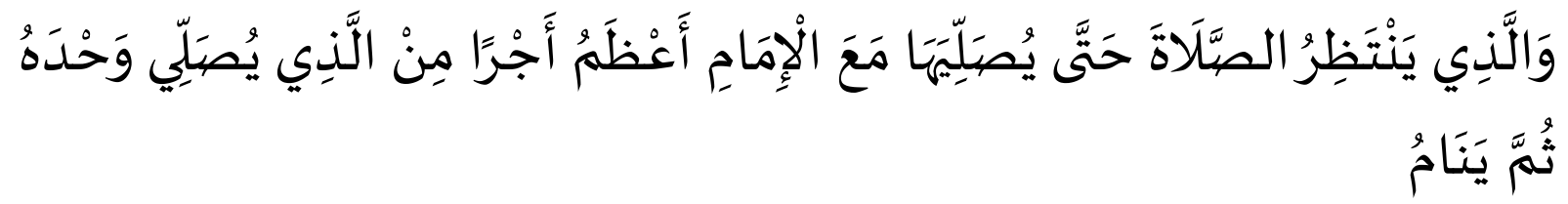

Maksudnya: Orang yang menunggu solat sampai solat bersama imam, lebih besar pahalanya dari orang yang solat sendirian kemudian tidur. (al-Bukhari: 1047, Muslim: 466)

Dua hadis di atas menunjukkan bahawa keharusan solat bersendirian. Hadis pertama secara zahir menunjukkan orang yang solat sendiri tidak menunggu Jemaah kurang pahalanya manakala hadis kedua menunjukkan keharusan solat bersendirian setelah diperintahkan oleh nabi SAW.

Perbincangan: Terdapat hadis Rasulullah SAW yang memberi ancaman keras keatas orang-orang yang meninggalkan solat berjemaah. Hadis tersebut menunjukkan kewajipan berjemaah. Maka setiap perkara wajib itu adalah syarat kepada sahnya solat. Sekiranya seseorang itu tidak berjemaah, maka solatnya tidak sah. Oleh itu, solat bersendirian yang dilakukan juga adalah tidak sah (al-Kahlani, n.d; Ibn Qayyim, 2000:63).

\subsection{RUMUSAN PERBINCANGAN TERHADAP PENDAPAT YANG RAJIH}

Setelah diteliti dalil serta perbincangan yang telah disebutkan dalam ruangan pendalilan, terdapat pelbagai dalil yang masing-masing mempunyai kekuatan dan konteks tersendiri. Sebagai panduan dalam membuat kesimpulan dalam kajian ini, kitab-kitab mu 'tamad dalam mazhab Syafie yang membicarakan mengenai perihal solat berjemaah dikonklusikan sebagai menerima hukum wajib fardu kifayah sebagai hukum bagi solat berjemaah

1. Al-Majmu' Sharh al-Muhadhdhab oleh Muhyiddin al-Nawawi (t.t.), Jilid 4, Bab Salat al-Jama'ah, mukasurat 284:

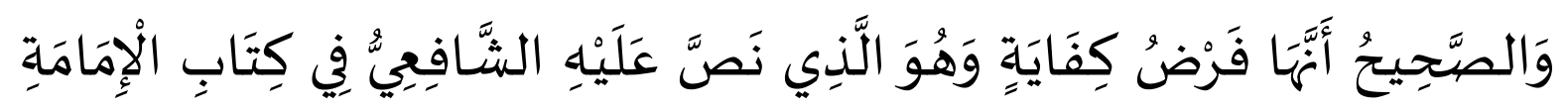

Maksudnya: Dan pendapat yang sahihnya hukum solat berjemaah adalah fardu kifayah dan inilah yang disebutkan oleh imam al-syafie didalam kitabnya "al-imamah"

2. Raudat al-Talibin oleh Muhyiddin al-Nawawi (1991), Jilid 1, Kitab Salat al-Jama'ah, muka surat 338:

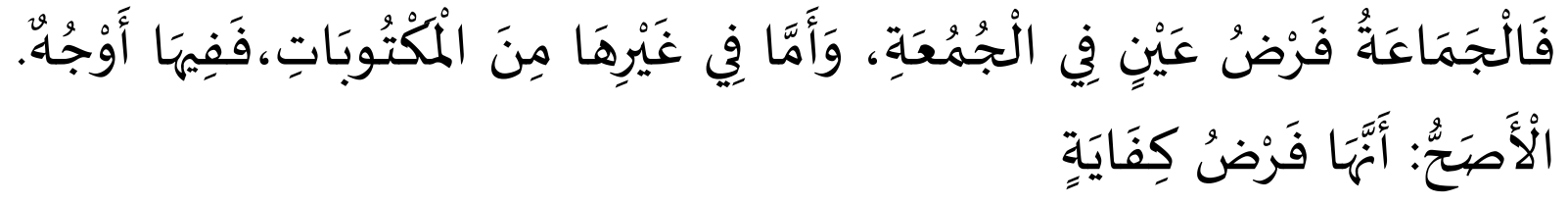

Maksudnya: Maka solat berjemaah bagi solat jumaat hukumnya fardu ain. Adapun bagi solat-solat fardu lima waktu terdapat beberapa hukum dan yang paling kuat adalah fardu kifayah 
3. Minhaj al-Talibin oleh Muhyiddin al-Nawawi (2005), Kitab Salat al-Jama'ah, mukasurat 38:

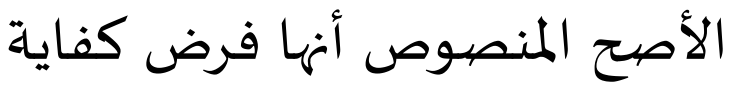

Maksudnya: Dan yang paling kuat sebagaimana yang disebutkan ialah solat berjemaah hukumnya fardu kifayah.

4. Nihayat al-Muhtaj oleh Shams al-Din Muhammad al-Ramli (1984), Kitab Salat al-Jama'ah wa ahkamuha, jilid 2 mukasurat 142:

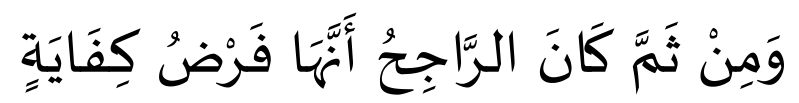

Maksudnya: Dan dari itu pendapat yang kuat tentang hukum solat berjemaah bagi solat fardu adalah fardu kifayah

5. Mughni al-Muhtaj oleh al-Khatib al-Sharbini (1994), Kitab Salat al-Jama'ah muka surat 466:

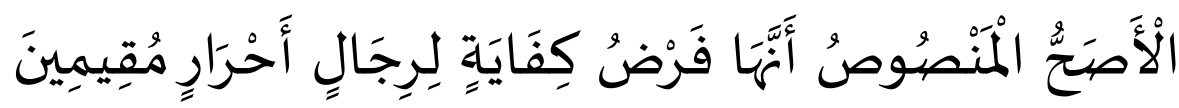

Maksudnya: Dan pendapat terkuat yang telah disebutkan mengenai hukum berjemaah bagi solat fardu adalah fardu kifayah kepada lelaki-lelaki yang merdeka dan bermukim

Oleh yang demikian, pendapat yang menyatakan hukum wajib fardu kifayah bagi solat berjemaah adalah lebih diutamakan seperti kebanyakan pandangan al-Nawawi (al-Majmu', tt: 284; al-Raudhah, 1991:338; al-Minhaj, 2005:38). Pandangan tersebut turut disokong oleh ulama' Syafie yang lain seperti Syeikh al-Ramli dan al-Syarbini (al-Nihayah, 1984:142; al-Mughni, 1994:466). Selain itu, pandangan tersebut diperkuatkan lagi dengan kajian kontemporari yang menyatakan bahawa hukum solat berjamaah bagi solat fardu adalah fardu kifayah kerana ia merupakan pendapat yang masyhur dan menjadi pegangan sebilangan besar para ulama' Syafie (Abdul Aziz, 1999:565; Mohd Salleh, 2003:7). Setelah dianalisis dari sudut pendalilan, hukum tersebut adalah lebih rajih kerana beberapa sebab (Zulkifli \& Mohd Khairuddin,2005:55):

a) Lebih menepati ajaran Islam yang menyuruh umatnya agar menegakkan syiar-syiar Islam.

b) Terdapat hadis yang mengancam orang yang tidak solat berjemaah dan ada juga hadis yang menekankan tentang kelebihan solat berjemaah bagi solat fardu. Oleh yang demikian, jalan tengah adalah penyelesaian terbaik untuk menetapkan hukum solat berjemaah bagi solat fardu.

c) Dalil-dalil yang digunakan oleh pendapat ini selari dengan konteks hukum solat berjemaah dan metodologi usul fiqh mazhab Syafie.

Jika mewajibkan solat jamaah bagi solat fardu tentunya akan menyebabkan tidak sah solat fardu bagi yang melaksanakannya dengan bersendirian. Bahkan disana ada hadis yang bertaraf sahih memutuskan bahawa solat seorang diri juga diberi ganjaran oleh Allah SWT sekalipun sedikit iaitulah hadis yang menerangkan kelebihan solat fardu berjemaah dengan ganjaran dua puluh tujuh kali ganda lebih afdhal dari solat bersendirian yang hanya mendapat satu ganjaran sahaja. Hal ini menunjukkan bahawa solat fardu yang dilakukan dengan bersendirian masih tetap diakui sah oleh Allah SWT dan diberikan ganjaran walaupun sedikit berbanding solat fardu berjemaah yang fadhilatnya dua puluh tujuh kali lebih besar.

Kesimpulan yang dapat difahami dari penghuraian hukum solat berjamaah bagi solat fardu di atas ialah walaupun hukum solat berjamaah tidak diwajibkan bagi setiap muslim, namun ia amatlah digalakkan untuk 
dipraktikkan dalam kehidupan masyarakat muslim dengan tujuan menegakkan syiar berjamaah yang amat dituntut oleh Islam bagi memastikan Islam semakin kuat dan berkembang di serata dunia serta menzahirkan kekuatan Islam di mata masyarakat bukan Islam.

\subsection{KESIMPULAN}

Sesungguhnya Allah SWT banyak memberi anugerah dan kelebihan kepada umat Muhammad SAW lebihlebih lagi kita umatnya di akhir zaman dengan pelbagai kelebihan yang besar antaranya solat fardu. Apatah lagi jika solat fardu yang diperintahkan itu dapat kita tunaikan dengan berjemaah di tempat-tempat yang menyerlahkan syiar Islam seperti di masjid dan surau. Daripada huraian di atas berkaitan solat berjemaah dapat disimpulkan bahawa solat berjemaah merupakan kewajipan fardu kifayah kepada umat Islam menurut pendapat terkuat dalam mazhab Syafie. Hal ini dapat difahami daripada segala arahan tegas dan ancaman Rasulullah SAW melalui hadis-hadisnya menunjukkan betapa pentingnya solat berjemaah ke arah menegakkan syiar Islam dan memperkasa penghayatan Islam di tengah-tengah masyarakat supaya Islam dilihat sebagai agama yang lebih tinggi dan mulia dari agama lain.

\section{RUJUKAN}

Al-Quran.

‘Ali Mursi (2001). Qabs Min Hady al- Solah. Kaherah: Darul Huda

'Asqalani, Imam Ibn Hajar (1997). Fathul Bari, Penjelasan Kitab Sahih al-Bukhari (terjemahan). c.1. Jakarta : Pustaka Azzam. Ditahqiqkan oleh Syeikh Abdul Aziz Abdullah bin Baz

Abdul Aziz, A. (1999). Fiqh al-Kitab Wa al-Sunnah. c.1.j.1. Maktabah Dar al-Salam.

Abi Daud, S. A., (1995). Sunan Abi Daud. j. 1.Beirut, Lubnan: Maktabah al-Asriyah.

Al- Syaukani, M. A., (2003). Nail al-Authar Syarh Muntaqal akhbar minahadis sayyidil akhyar. j.1.c.2. Mansoura : Dar al-Wafa'Syawini

Al-A’rabi, A. B. (1995). Ahkam al-Quran. pentahkik Ali Muhammad al-Bajawi. Beirut : 'Alam al-Kutub

Al-Baghawi, A. M. (2000). Ma'alim al-Tanzil fi Ta'wil al-Quran. Beirut, Dar -Ihya' wa al-Turath.

Al-Subki, T. (1994). Kifayatul Akhyar fi Hilli Ghoyatul Ikhtisar. C.1. Damsyiq : Dar al-Khair.

Al-Syarbini, S. M., (1994). Mugni al-Muhtaj. j.1, c.1. Beirut: Dar al-Kutub al-Ilmiyyah

Al-Zamakhshari, M. A. (1987). al-Kashaf an Haqaiq al-Ghawamid al-Tanzil. Beirut, Dar al Kitab al-'Arabi.

As-Shātibī, M., (1997). al-Muwāfaqāt. Mesir, Dār Ibn 'affān.

Bujairimi, S. U., (1950). Hasyiah Bujairimi a'la Syarah al-Minhaj.Kaherah: Maktabah Halabi dan Ummah. Kuala Lumpur: Telaga Biru

Ibn 'Ashur, M. T. (1984). At-Tahri wa al-Tanwir. Tunisia, Dar at-Tunisiah li al-Nashir.

Ibn Manzur, (1994). Lisan al-'Arab. Beirut, Dar al-Sadr.

Ibn Qudamah, A. M. (1968). al-Mughni. Cairo, Egypt, Maktabah al-Qahirah.

Ibn Taymiyyah, T. D. (1995). Majmu' al-Fatawa. Medina, Majma al-Malik Fahad litiba'ah al-Mushaf al-Sharif.

Jawziyyah, Syamsuddin Muhammad Abi Bakr Ibn al-Qayyim (1998). Al-Solah Wa Hukmu Tarikuha. c.2.Beirut: Dar Ibn Hazm

Jurjani, Ali (1983). Al-Takrifat.C.1. Beirut, Lubnan : Darul Kutub Ilmiah 
Kahlani, M. I. (t.t.). Subul al-Salam, Dar al-Hadis.

Mohd Salleh, A. (2003). Solat Jamaah: Satu Penjelasan Hukum Menurut Mazhab

Mohd Subki, A. R., (2011). Solat Berjemaah Asas Kekuatan Peribadi, Masyarakat

Mubarakfuri, S. R. (t.t.). Rahiq al-Makhtum. Beirut, Dar al-Hilal.

Mubarkafuri, A. R., (2001).Tuhfah al-Ahwazi bi Syarh Jami’al-Tirmidzi. j.2.c.1.Kaherah: Dar al-Salam

Mughirah bin al-Bardazbah (2001). Shahih Bukhari. j.1. Kaherah, Dar al-Manar.

Muslim (1981). Sahih Muslim bi al-Sharh al-Nawawi. Cairo, al-Matba'ah al-Masriyyah wa Maktabuha.

Mustafa, A., et. al., (April 2004). Al-Fiqh al-Manhaji (terjemahan). c. 3. j.1. Jabatan Mufti Negeri Sembilan.

Muyiddin, N., (1991). Kitab Raudhah al-Thalibin Wa Umdah al-Muftin.c.3 j. 1. Beirut: Maktabah al-Islami.

Najdi, A. R. (1977). Hashiyah Rawdat al-Murba', no publisher.

Nasaei, H, A, R., A. (2003). Sunan Al-Nasaei, c.2. j. 1. Beirut, Lubnan: Dar al-Kutub al-Ilmiah.

Nawawi, A., Z. S., (t.t). Kitab al-Majmu’Syarah Muhadzab. j. 1. Jeddah: Maktabah al-Irsyad.

Nawawi, M. S. (2005). Minhaj al-Talibin Beirut, Dar al-Fikr.

Qazwini, M. B. Y. (2007). English Translation of Sunan Ibn Majah. Riyadh, Kingdom of Saudi Arabia, Maktaba Dar-us-Salam.

Qusyairi, A. H., (1995). Shahih Muslim. j. 9. Beirut: Dar al-Kutub al-Ilmiyyah

Rafi'i, A. K. (t.t.). Sharh al-Kabir. Beirut, Dar al-Fikr.

Ramli, M. A. (1984). Nihayat al-Muhtaj ila Sharh al-Minhaj. Beirut, Dar al-Fikr.

Syafie. Selangor: Pustaka Haji Abdul Majid

Tirmidzi, A. I. M. (t.t). Jami’al-Tirmizi. Arab Saudi: Bait al-Afkar al- Dauliyyah

Zuhayli, W. (1998). al-Tafsir al-Munir fi al-'Akidah Wa al-Shari'ah Wa al-Manhaj. Beirut, Dar al-Fikr al-Muasir.

Zuhayli, W. (t.t.). Al-Figh al-Islami Wa Adillatuhu. Damascus, Dar al-Fikr.

Zulkifli, M. \& Mohd Khairuddin, A. (2005). Hukum Wanita Menjadi Imam Solat: Kontroversi Solat Jumaat Dr Amina Wadud. Selangor: Darul Fuqaha' Enterprise. 